UDK $630 * 52: 311$

\title{
GEOSTATISTICAL TECHNIQUE FOR GROWING STOCK ESTIMATES ON SMALL FOREST STANDS USING INVENTORY, ENVIROMENTAL AND LANDSAT 8 DATA
}

\author{
Geostatistička tehnika procjene drvnih zaliha u šumskim sastojinama male površine na \\ bazi inventurnih, okolišnih i spektralnih podataka Landsat 8 \\ Azra Čabaravdić ${ }^{1}$, Merisa Osmanović ${ }^{2}$, Galib Mahmutović ${ }^{3}$, Sanela Mulić ${ }^{4}$
}

\begin{abstract}
Regular forest inventory on state owned forest delivers plenty of data and information enabling detailed insight in forest structure and quantities. Current methodology for forest assessment on private properties considers time-consuming, low-intensive terrestrial measurement and observation on scattered small forest stands distributed on hilly and plane position around complex of state owned forests.

Here are evaluated two modeling techniques: ordinary least square (OLS) regression and geographically weighted regression (GWR) estimating growing stock quantities of point sample inside the smallest state owned forest stands (area less then $10 \mathrm{ha}$ ). Used material contained forest attributes local estimates from regular inventory distributed in unique management class: beech and fir mixed forest on deep silicate soil, environmental and transformed spectral Landsat 8 data.

Obtained results pointed out statistical significance of normalized standardized spectral radiance of NIR and SWIR Landsat bands in regression models. The GWR estimates achieve up to almost $30 \%$ higher variability explanation then OLS models. Also, GWR showed wider range then OLS estimates with smaller prediction errors. Evaluation on sample stand level resulted in reliable estimates of particular species or groups and total mean growing stock for all small stands. Further research about potential of GWR and other geo-statistical techniques for forest attribute estimates on more intensive point sample inside small spatial unit and/or whole spatial unit is recommended.
\end{abstract}

Key words: growing stock, geographically weighted regression, forest inventory, environmental data, Landsat 8

\footnotetext{
${ }^{1}$ University of Sarajevo, Faculty of Forestry

${ }^{2}$ University of Sarajevo, Institute of forestry and urban greenery

${ }^{3}$ Public enterprise „Šume TK“ d.d. Kladanj

${ }^{4}$ Private enterprise „Wald-projekt" d.o.o Bosanska Krupa
} 


\section{INTRODUCTION - Uvod}

Recent studies about forest characteristics on large area integrate all available information compiled with multivariate analysis and geographic information system tools.

Lately forest terrain observations and measurements, environmental and remote sensing data are used as for land use classification so for prediction of forest end environmental management related variables (BARHOSA ET AL.,2013; GÜNLÜ ET aL.,2014; MATtioli ET AL.,2012; MCRoBeRTS ET AL.,2010; Osmanović ET AL.,2016; VAN DER LAAN ET AL.,2014).

Periodical intensive forest inventory on state owned management unit level deliver plenty of data and information for statistical characterization of forest resources. Knowing that spatial variation of forest characteristics over space could be modeled it is interesting to examine if regression based estimation of the most important forest attributes on small stands outside of forest complex are efficient enough to use such approach for private forest characterization.

Usually private forest properties are distributed on hilly sides around state forests and/or randomly scattered around with small area. Current forest resource characterization on private properties is based on limited measurement and ocular classification and estimation mainly without possibility to determine statistical estimation error. So compilation of terrestrial, environmental and spectral data could be examined in order to estimates forest characteristics on scattered small areas. Such possibility opens alternative solution for current time-consuming and manly nonreliable forest production estimates as the most important management information of private forest.

In this paper are developed and compared OLS and GWR regression models for the growing stock using forest inventory sample divided on the sub sample covering stands with more than 10 ha size and the sub sample with smaller stands (less then 10 ha) compiled with environmental and Landsat 8 spectral data. Estimates are developed using the first sub sample and evaluated on known ground data on the second sub sample.

\section{MATERIAL AND METHODS OF RESEARCH - Materijal i metode istraživanja}

Study area includes part of the state owned forest stands in Management unit Oskova. Study area, also as a part of the Forest Management area "Sprečko" is located in the north east part of Bosnia situated between Longitudes $18^{\circ} 29-18^{\circ} 37^{\prime}$ and Latitudes $44^{\circ} 23-44^{\circ} 17^{\prime}$ (Figure 1). 


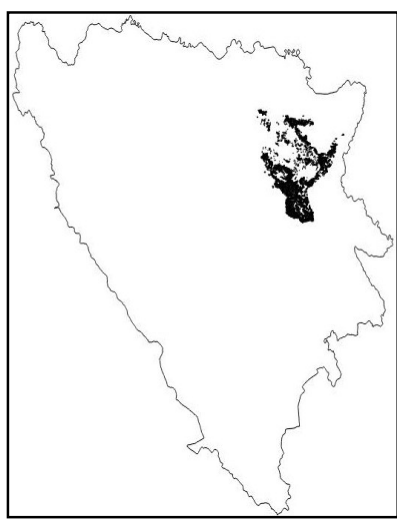

a.

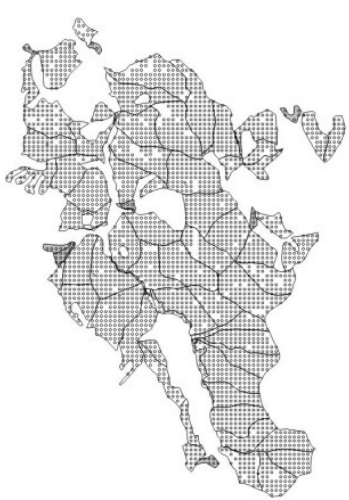

b.

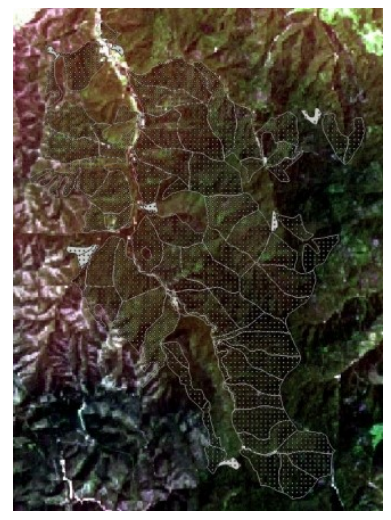

c.

Figure 1. Forest management area (a.) study area with stands and sampling plan (b.) (small stands - grey) and study area Landsat 8 segment (c.)

Slika 1. Šumsko-gospodarsko područje (a.), područje istraživanja sa uređajnom podjelom $i$ planom uzorka (b.) (male sastojine - sivo) i dio Landsat 8 snimka

The terrestrial measurement for the research was conducted in the summer 2012 and was part of regular forest inventory. Terrestrial sample in this study consists of 3034 sample plots distributed on square grid of 200 meter distance covering unique management class (code 1203). Each sample plot was consisted of system of concentric circles with one centre and different range radius. Forests species, diameter at the breast height and height are recorded as geo-position of circle centre and local estimates of forest attributes (growing stock total, per groups and the main species) are produced following standard inventory procedure. According to management classes classification chosen management class is named as beech and fir mixed forest on deep silicate soils.

Ground sample is divided in two sub samples: the first one consisting sample points in stands with more then 10 ha size $(n=2993)$ and the second sub sample with smaller stands (less then $10 \mathrm{ha})(\mathrm{n}=41)$.

Table 1.Growing stock $\left(\mathrm{m}^{3} / \mathrm{ha}\right)$ descriptive statistic of sample in stands larger then 10 ha $(\mathrm{n}=2993)$

Tabela 1. Deskriptivna statistika uzorka drvne zalihe $\left(\mathrm{m}^{3} / \mathrm{ha}\right)$ odjeljenja vecih od 10 ha $(n=2993)$

\begin{tabular}{lccccc}
\hline & Mean & Std. Dev. & Min & Max & CI $(95.0 \%)$ \\
\hline Fir & 95.33 & 128.12 & 0 & 828 & 4.62 \\
Beech & 237.45 & 187.27 & 0 & 990 & 6.75 \\
Conifers & 98.95 & 130.11 & 0 & 900 & 4.69 \\
Broadleaves & 263.88 & 186.85 & 0 & 1028 & 6.74 \\
Total & 362.81 & 177.44 & 2 & 1051 & 6.40 \\
\hline
\end{tabular}


Information about forest stands with area less then 10 ha are given in table 2. Table 2. Information about forest stands less then 10 ha (small stands)

Tabela 2. Informacije o šumskim sastojinama manjim od 10 ha (male sastojine)

\begin{tabular}{ccccc}
\hline Small stand & Compartment & Stand & Area (ha) & Sample size (n) \\
\hline 1 & 066 & 03 & 6.62 & 6 \\
2 & 085 & 01 & 9.78 & 9 \\
3 & 107 & 01 & 3.51 & 3 \\
4 & 048 & 02 & 5.77 & 5 \\
5 & 028 & 03 & 3.85 & 2 \\
6 & 086 & 01 & 7.90 & 6 \\
7 & 005 & 05 & 7.68 & 5 \\
8 & 038 & 03 & 4.97 & 4 \\
\hline
\end{tabular}

Table 3. Descriptive statistic of sample growing stock in stands smaller then 10 ha

Tabela 3. Deskriptivna statistika drvne zalihe uzorka u odjeljenjima manjim od $10 \mathrm{ha}$

\begin{tabular}{c|l|rrrrr}
\hline Stand & Statistic & Fir & Beech & Conifers & Broadl. & Total \\
\hline \multirow{2}{*}{1} & Mean & 49.8 & 81.8 & 126.3 & 105.7 & 232 \\
& Std. Dev. & 53.6 & 69.4 & 76.6 & 63.3 & 131 \\
\hline \multirow{2}{*}{2} & Mean & 162 & 233.7 & 169.7 & 245.9 & 415 \\
& Std. Dev. & 183 & 163.3 & 180.7 & 153.3 & 229 \\
\hline \multirow{2}{*}{3} & Mean & 0 & 73.7 & 0 & 155.7 & 156 \\
& Std. Dev. & 0 & 68 & 0 & 67.9 & 67.9 \\
\hline \multirow{2}{*}{4} & Mean & 27.8 & 163 & 62.8 & 253.2 & 316 \\
& Std. Dev. & 39 & 142.8 & 73.4 & 113.8 & 138 \\
\hline \multirow{2}{*}{5} & Mean & 175 & 78.5 & 174.5 & 148.5 & 323 \\
& Std. Dev. & 19.1 & 0.7 & 19.1 & 98.3 & 79.2 \\
\hline \multirow{2}{*}{6} & Mean & 118 & 299.2 & 117.5 & 299.2 & 417 \\
& Std. Dev. & 72 & 160.6 & 72 & 160.6 & 150 \\
\hline \multirow{2}{*}{7} & Mean & 84.6 & 95 & 84.6 & 106.6 & 191 \\
& Std. Dev. & 84.1 & 50.5 & 84.1 & 50.6 & 81.3 \\
\hline \multirow{2}{*}{8} & Mean & 25.5 & 227.3 & 25.5 & 241.8 & 268 \\
& Std. Dev. & 43.4 & 84.4 & 43.4 & 102 & 65.3 \\
\hline
\end{tabular}

As additional information here are used environmental data obtained using digital elevation model: slope, aspect, hill shade and altitude. Hill shade is calculated using information about elevation and azimuth of Landsat 8 satellite image complied in this study. 
Table 4. Descriptive statistic of environmental data sample in stands larger then 10 ha $(\mathrm{n}=2993)$

Tabela 4.. Deskriptivna statistika okolišnih podataka uzorka u odjeljenjima većim od 10 ha $(n=2993)$

\begin{tabular}{l|ccccc}
\hline & Mean & Std. Dev. & Min & Max & CI (95.0\%) \\
\hline Slope & 19.79 & 8.11 & 0 & 49 & 0.29 \\
Aspect & 203.18 & 108.69 & 0 & 360 & 3.92 \\
Hill shade & 113.95 & 56.66 & 0 & 240 & 2.04 \\
Altitude & 698.63 & 172.53 & 350 & 1143 & 6.22 \\
\hline
\end{tabular}

A Landsat 8 imagery (Path 188/Row 29) covered the study area and was acquired on 21 July 2015. The pre-processing of the image included merging bands in one image, assigning projection that fits Bosnia $(\mathrm{E}=3908)$, changing image resolution to $20 \mathrm{~m}$ and extraction the study area from satellite image. Then digital values transformation was completed calculation top of reflection values. Not all bands were included in the research. It was used reflectance of six spectral bands [Blue ${ }_{\mathrm{RT}}, \operatorname{Red}_{\mathrm{RT}}$, Green $_{R T}$, Near infrared $\left(\mathrm{NIR}_{\mathrm{RT}}\right)$ and two short wave infrared $\left(\mathrm{SWIR} 1_{\mathrm{RT}}\right.$ and SWIR2 $2_{\mathrm{RT}}$ bands). The pre-processing is performed using QGIS Open Source.

In this study two statistical approaches were used: parametrical ordinary leastsquares regression (OLS) and geo-statistical technique: geographically weighted regression (GWR). For OLS regression is used Statgraphics Plus 5.0 and GWR regression analysis is applied using Windows Application for Geographically Weighted Regression Modeling GWR4 (NAKAYA 2014).

The OLS regression is the most commonly statistical technique used for estimating forest attributes, where the depended variable is estimated by producing unbiased minimum sum of squared residuals depending of the predictors (MONTGOMERY ET AL., 2001). The equation used to perform OLS is given below:

$$
\hat{Y}_{i}=\hat{\beta}_{0}+\hat{\beta}_{1} X_{1}+\ldots+\hat{\beta}_{n} X_{n}+\varepsilon_{i}
$$

where $\hat{Y}_{i}$ is the dependent variable (in this case represents the growing stock estimated), $\mathrm{X}_{1} \ldots \mathrm{X}_{\mathrm{n}}$ are the independent or predictors (in this case environmetal and spectral data), $\hat{\beta}_{0}$ is the intercept parameter, $\hat{\beta}_{1} \ldots \hat{\beta}_{\mathrm{n}}$ are the regression coefficients, and $\varepsilon_{\mathrm{i}}$ are the regression residuals. Regression models, based on correlation anaylsis, are determined using stepwise regression and normalised standardized predictors.

The same statisticaly significant predictors are used in GWR models. Geographically weighted regression considers geographically varying parameters. Conventional (Gaussian) GWR model is described by the equation:

$$
\hat{\mathrm{Y}}_{\mathrm{i}}=\sum_{\mathrm{k}} \beta_{\mathrm{k}}\left(\mathrm{u}_{\mathrm{i}}, \mathrm{v}_{\mathrm{i}}\right) \mathrm{x}_{\mathrm{k}, \mathrm{i}}+\varepsilon_{\mathrm{i}}
$$


where $\hat{\mathrm{Y}}_{\mathrm{i}}, \mathrm{x}_{\mathrm{k}, \mathrm{i}}$, and $\varepsilon_{\mathrm{i}}$ are, respectively, dependent variable, kth independent variable, and the Gaussian error at location $i,\left(\mathrm{u}_{\mathrm{i}}, \mathrm{v}_{\mathrm{i}}\right)$ is the $\mathrm{x}, \mathrm{y}$ coordinate of the kth location, and coefficients $\beta_{\mathrm{i}}\left(\mathrm{u}_{\mathrm{i}}, \mathrm{v}_{\mathrm{i}}\right)$ are varying conditions on the location (NAKAYA 2014). To fit a Gaussian GWR model it is necessary to specify several inputs behind dependent variable and predictors: (1) location variables as (x, y) coordinates, (2) character of independent variable (local, global) and (3) the kernel function for geographical weighting to estimate local coefficients, its bandwidth size, and model selection criteria that are necessary for finding the best bandwidth and for comparing it with other modeling results using the same data. Here are used terrain geo-location of sample plots $(\mathrm{x}, \mathrm{y})$, local character independent variables, fixed Gaussian distance, golden section search for optimal bandwidth size and AICc criterion. Detailed method and procedure description are given in NAKAYA (2014) and CHARLTON ET AL. (2006).

For OLS and GWR models determinations and correlation coefficients are obtained and compared. Growing stock estimates on known sample-based geolocation in small forest stand (less then $10 \mathrm{ha}$ ) are determined as prediction on nonsampled points. Samples based on OLS and GWR estimates are then compared with terrestrial determined samples using t-test for each small stand.

Also, growing stock distribution for broadleaves and conifers are compared in order to analyze differences in ranges of OLS and GWR estimates.

\section{RESULTS - Rezultati istraživanja}

In order to perform OLS and GWR regressions modelling, correlation between target variables (growing stock for the main species, groups: conifers and broadleaves and total) and spectral and environmental predictors are calculated (Table $5)$.

Table5. Correlation matrix between growing stock and predictors (environmental and spectral data)

Tabela 5. Korelaciona matrica drvne zalihe i prediktora (okolišni i spektralni podaci)

\begin{tabular}{|c|c|c|c|c|c|}
\hline & Fir & Beech & Conifers & Broadleaves & Total \\
\hline Blue $_{\mathrm{RT}}$ & -0.20 & -0.05 & -0.20 & 0.02 & -0.13 \\
\hline Green $_{R T}$ & -0.22 & 0.02 & -0.22 & 0.08 & -0.08 \\
\hline $\operatorname{Red}_{R T}$ & -0.19 & -0.02 & -0.18 & 0.04 & -0.10 \\
\hline $\mathrm{NIR}_{\mathrm{RT}}$ & -0.33 & 0.28 & -0.34 & 0.31 & 0.07 \\
\hline SWIR $1_{\mathrm{RT}}$ & -0.38 & 0.27 & -0.40 & 0.32 & 0.04 \\
\hline SWIR2 $2_{R T}$ & -0.37 & 0.23 & -0.38 & 0.27 & 0.00 \\
\hline Slope & -0.11 & 0.03 & -0.11 & 0.06 & -0.02 \\
\hline Aspect & 0.03 & 0.05 & 0.03 & 0.03 & 0.06 \\
\hline Hill shade & -0.09 & -0.08 & -0.09 & -0.08 & -0.15 \\
\hline Altitude & 0.04 & 0.12 & 0.05 & 0.08 & 0.12 \\
\hline
\end{tabular}


The highest correlations are obtained between species and groups of target variables with spectral $\mathrm{NIR}_{\mathrm{RT}}, \mathrm{SWIR} 1_{\mathrm{RT}}$ and SWIR2 $2_{\mathrm{RT}}$ predictors. It is visible that correlations with environmental data are very low and insignificant manly. Applying stepwise regression significant predictors are identified and models are determined. Parameter of OLS regression models are given in following equations:

$\hat{\mathrm{y}}_{\mathrm{fir}_{\mathrm{i}}}^{\mathrm{OLS}}=306.11+0.16 \mathrm{NIR}_{\mathrm{z}_{\mathrm{i}}}-1.42 \mathrm{SWIR} 1_{\mathrm{z}_{\mathrm{i}}}+\varepsilon_{\mathrm{i}}$

$\hat{\mathrm{y}}_{\text {beech }_{\mathrm{i}}}^{\text {OLS }}=78.45+0.54 \mathrm{NIR}_{\mathrm{z}_{\mathrm{i}}}+1.76 \mathrm{SWIR1}_{\mathrm{z}_{\mathrm{i}}}+\varepsilon_{\mathrm{i}}$

$\hat{\mathrm{y}}_{\text {conifers }}^{\text {OLS }}=317.12+0.27 \mathrm{NIR}_{\mathrm{z}_{\mathrm{i}}}-1.61 \mathrm{SWIR1}_{\mathrm{z}_{\mathrm{i}}}+\varepsilon_{\mathrm{i}}$

$\hat{\mathrm{y}}_{\text {broadleaves }_{\mathrm{i}}}^{\text {OLS }}=198.12+5.53 \mathrm{SWIR}_{\mathrm{z}_{\mathrm{i}}}-5.54 \mathrm{SWIR} 2_{\mathrm{z}_{\mathrm{i}}}+\varepsilon_{\mathrm{i}}$

$\hat{\mathrm{y}}_{\text {total }_{\mathrm{i}}}^{\mathrm{OLS}}=374.29+0.96 \mathrm{NIR}_{\mathrm{z}_{\mathrm{i}}}-1.31 \mathrm{SWIR} 2_{\mathrm{z}_{\mathrm{i}}}+\varepsilon_{\mathrm{i}}$

It is obtained that significant predictors for regression modeling are combination of NIR $R_{R T}$ and SWIR $_{R T}$ bands.

determined:

The same predictors are used for GWR modeling and following models are

$\hat{y}_{\text {fir }_{i}}^{G W R}=299.19\left(X_{i}, Y_{i}\right)-0.05\left(X_{i}, Y_{i}\right) N I R z_{z_{i}}-1.14\left(X_{i}, Y_{i}\right) S W I R 1_{z_{i}}+\varepsilon_{i}$

$\hat{y}_{\text {beech }_{i}}^{G W R}=122.17\left(X_{i}, Y_{i}\right)+0.12\left(X_{i}, Y_{i}\right) N_{I R} z_{z_{i}}+0.95\left(X_{i}, Y_{i}\right) S W I R 1_{z_{i}}+\varepsilon_{i}$

$\hat{y}_{\text {conifers }_{i}}^{G W R}=306.71\left(X_{i}, Y_{i}\right)-0.04\left(X_{i}, Y_{i}\right) N_{R} z_{z_{i}}-1.20\left(X_{i}, Y_{i}\right) S W I R 1_{z_{i}}+\varepsilon_{i}$

$\hat{y}_{\text {broadleaves }_{\mathrm{i}}}^{\text {GWR }}=190.401\left(\mathrm{X}_{\mathrm{i}}, \mathrm{Y}_{\mathrm{i}}\right)+3.07\left(\mathrm{X}_{\mathrm{i}}, \mathrm{Y}_{\mathrm{i}}\right) \mathrm{SWIR} \mathrm{z}_{\mathrm{z}_{\mathrm{i}}}-2.67\left(\mathrm{X}_{\mathrm{i}}, \mathrm{Y}_{\mathrm{i}}\right) \mathrm{SWIR} 2_{\mathrm{z}_{\mathrm{i}}}+\varepsilon_{\mathrm{i}}$

$\hat{\mathrm{y}}_{\text {total }_{\mathrm{i}}}^{\mathrm{GWR}}=350.411\left(\mathrm{X}_{\mathrm{i}}, \mathrm{Y}_{\mathrm{i}}\right)+0.21\left(\mathrm{X}_{\mathrm{i}}, \mathrm{Y}_{\mathrm{i}}\right) \mathrm{NIR}_{\mathrm{z}}-0.147\left(\mathrm{X}_{\mathrm{i}}, \mathrm{Y}_{\mathrm{i}}\right) \mathrm{SWIR} 2_{\mathrm{z}}+\varepsilon_{\mathrm{i}}$

Geographically weighted regression considers local character of predictors with estimates of coefficient means in equations above. So, prediction values are connected with varying geo-position of circle centre in relation with predictors.

Following figures present observed versus predicted growing stock quantities of two regression types for broadleaves and conifers that are similar as the main species: beech and fir too. 


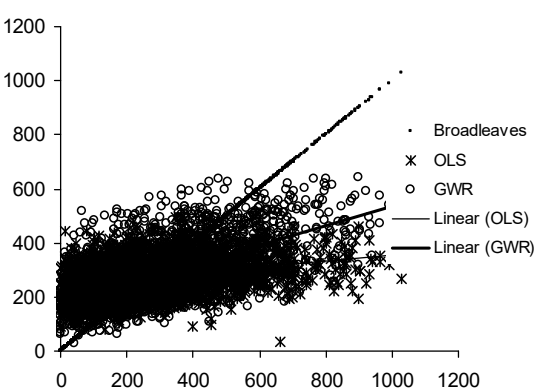

a.

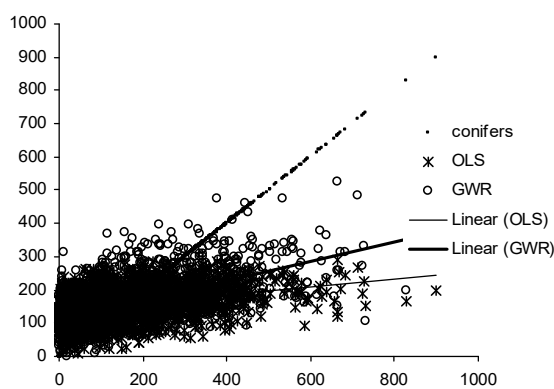

b.

Figure 1. Observed versus OLS and GWR predicted growing stock for broadleaves (a.) and conifers (b.)

Slika 1. Observirane prema OLS $i$ GWR procjenjenim vrijednostima drvne zalihe za lišćare (a.) i četinare (b.)

Both regression methods show in average overestimated quantities less then ground observations and underestimate quantities above ground average. But it is visible that GWR slopes for both broadleaves and conifers are closer to ground observation then OLS slopes.

Determination and correlation of OLS and GWR models are given in table 6. The GWR models deliver higher determinations then OLS models. Determination improvement is achieved for all models and ranges from $18 \%$ to $30 \%$.

Table 6. Determination and correlation of OLS and GWR models

Tabela 6. Determinacije i koeficijenti korelacija OLS i GWR modela

\begin{tabular}{l|ccccc}
\hline \multirow{2}{*}{} & \multicolumn{2}{|c}{ OLS } & \multicolumn{2}{c}{ GWR } & \multirow{2}{*}{$\Delta \mathrm{R}^{2}$} \\
\cline { 2 - 5 } & $\mathrm{R}^{2}$ & $\mathrm{R}$ & $\mathrm{R}^{2}$ & $\mathrm{R}$ & \\
\hline Fir & 0.11 & 0.33 & 0.29 & 0.54 & 0.18 \\
Beech & 0.07 & 0.27 & 0.32 & 0.57 & 0.25 \\
Conifers & 0.12 & 0.35 & 0.32 & 0.57 & 0.20 \\
Broadleaves & 0.11 & 0.33 & 0.40 & 0.63 & 0.29 \\
Total & 0.02 & 0.13 & 0.24 & 0.49 & 0.22 \\
\hline
\end{tabular}

Finally, evaluation of OLS and GWR growing stock estimates using corresponding sample on stand level using t-test was performed for stands with less then 10 ha area (Table 7.): 
Table 7. Evaluation of OLS and GWR growing stock estimates on stand level using t-test (pvalue)

Tabela 7. Evaluacija OLS i GWR procjena drvne zalihe na nivou sastojine pomoću t-testa (pvrijednost)

\begin{tabular}{c|cc|cc|cc|cc|cc}
\hline Stand & \multicolumn{2}{|c|}{ Fir } & \multicolumn{2}{c|}{ Beech } & \multicolumn{2}{c|}{ Conifers } & \multicolumn{2}{c|}{ Broadleaves } & \multicolumn{2}{c}{ Total } \\
\hline & OLS & GWR & OLS & GWR & OLS & GWR & OLS & GWR & OLS & GWR \\
1 & 0.09 & 0.26 & 0.10 & 0.06 & 0.72 & 0.82 & 0.02 & 0.01 & 0.19 & 0.06 \\
2 & 0.24 & 0.21 & 0.36 & 0.67 & 0.73 & 0.20 & 0.35 & 0.50 & 0.81 & 0.71 \\
3 & - & - & 0.67 & 0.40 & - & - & 0.06 & 0.08 & 0.02 & 0.03 \\
4 & 0.00 & 0.73 & 0.38 & 0.89 & 0.06 & 0.50 & 0.79 & 0.43 & 0.80 & 0.47 \\
5 & 0.47 & 0.66 & 0.06 & 0.10 & 0.49 & 0.65 & 0.48 & 0.73 & 0.80 & 0.70 \\
6 & 0.56 & 0.75 & 0.74 & 0.15 & 0.58 & 0.81 & 0.89 & 0.16 & 0.54 & 0.10 \\
7 & 0.79 & 0.40 & 0.12 & 0.06 & 0.76 & 0.34 & 0.00 & 0.05 & 0.01 & 0.04 \\
8 & 0.76 & 0.47 & 0.86 & 0.67 & 0.75 & 0.53 & 0.39 & 0.64 & 0.08 & 0.09 \\
\hline
\end{tabular}

(Statistically significant at $\mathrm{p}<0.05$ )

Obtained results related to significance of mean differences between ground and estimated sample values show non-significant differences for species or/and groups/total for both methods mainly.

Then, we found that important information about possible estimates is related to sampling distribution of target variables. So here are graphically presented growing stock distributions for sample and predictions based on OLS and GWR models. Following figures present comparative growing stock distribution of sample and predictions for broadleaves (Figure 2.) and conifers (Figure 3.).
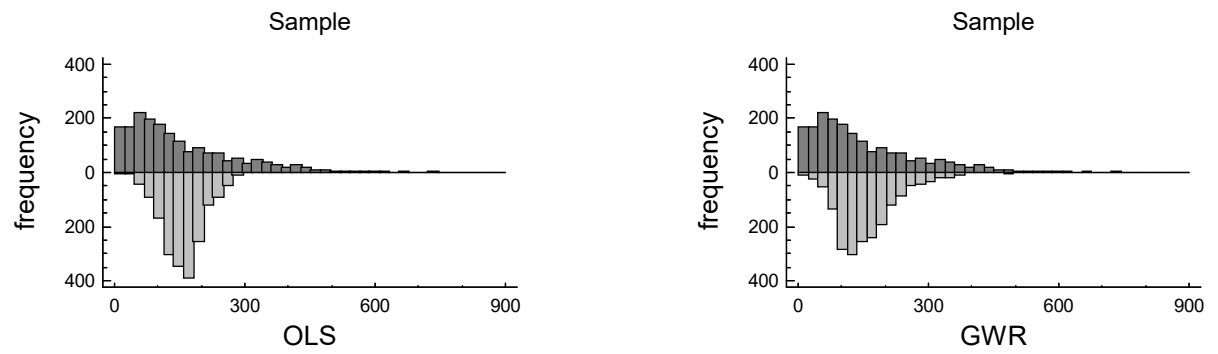

Figure 2. Distribution of OLS and GWR growing stock predictions for conifers Slika 2. Raspodjela OLS i GWR procjena drvne zalihe četinara 

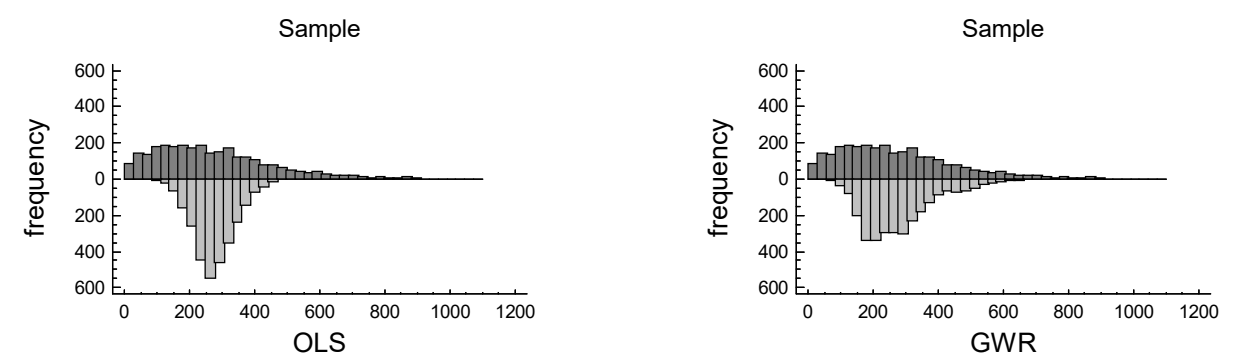

Figure 3. Distribution of OLS and GWR growing stock predictions for broadleaves Slika 3. Raspodjela OLS i GWR procjena drvne zalihe lišćara

It is visible that GWR growing stock distributions have wider range and closer shape to ground distributions then OLS distributions for both groups (broadleaves, conifers).

\section{DISCUSSION - Diskusija}

Potentials of compilation of all available terrestrial and remote sensing data about forest resources and recent technological achievements in GIS intensified research about application of geo-statistical techniques which are more advanced then standard regression based estimates of forest attributes (AKHAVAN ET AL., 2015; PROPAStIN 2008; Propastin ET AL., 2012; ZhANG ET AL., 2008). Geo-statistically weighted regression has been recognized and examined in different forest and environmental conditions delivering more reliable estimates then ordinary leastsquares regression (BENITEZ ET AL., 2016; CHEN ET AL., 2012; SHRIESTA 2006; TIRYANA ET AL., 2010).

Significant correlations between spectral data and forest attributes are found and presented in this paper confirmed their role as in quoted researches where particular spectral bands or their transformations also become significant predictors. Also, GWR estimates deliver higher determinations up to $30 \%$ for all forest attributes then OLS estimates in all environmental conditions.

Related to sample means differences the OLS estimates give better results than GWR for some small stands. ZHANG ET AL., (2008) found that OLS estimates are appropriate in homogenous forest stands without spatial autocorrelation (regularly distributed over space). Authors reported that GWR gave more accurate precision in case of clustered or randomly distributed trees over space. These points out the role of spatial patterns of plot (tree) locations. So detailed spatial pattern analysis should contribute to regression method selection too.

Analyzing whole ground sample and its estimates, the GWR preserves variability better what is influential for point based estimations (Figure 3.). 
Obtained results show potentials of OLS and GWR to integrate in small stand estimations to calculate not only forest attribute mean estimates then error assessment as on stand so for management class level.

\section{CONCLUSIONS - Zaključci}

Here are applied OLS and GWR regression estimates of forest attributes on geo-located points distributed on regular sampling scheme in order to connect with current standard inventory methodology.

The results of this study indicate that the geographically weighted regression method was more accurate in representing the variability of growing stock, providing up to $30 \%$ higher $\mathrm{R}^{2}$ then ordinary least square regression. Then comparing observed and estimated values it is visible that, in average, GWR estimates are more close to observed then OLS estimates. Also, GWR growing stock estimates distributions cover larger range of values so it could be expected that this method preserve attributes variability more realistic on dispersed small forest stands with clustered or randomly distributed trees mainly situated on hilly position around state owned forests.

In this case only transformed spectral Landsat 8 bands data were found as significant so further research could analyze other transformation as vegetation indexes, Tassel Cap and/or PCA components.

Obtained results indicate possibility to apply GWR on more intensive geolocated points sample inside small stand. Also, GWR has potential to determine estimates and statistics for whole spatial units what could be analyzed in further research as other geo-statistical techniques compiling inventory, environmental and spectral data (MENG 2014).

\section{REFERENCES - Literatura}

AkHavan, R., Kia-DaliRi, H., Etemad, V. (2015): Geostatistically estimation and mapping of forest stock in a natural unmanaged forest in the Caspian region of Iran. Caspian Journal of Environmental Sciences. Vol. 13, No. 3, pp 61- 76.

Barhosa, M.J., Melendez - PAstor, I., NAVARRo - Pedreño, J. AND Bitencourt, D.M. (2013): Remotely sensed biomass over steep slopes: An evaluation among successional stands of the Atlantic Forest, Brazil. ISPRS Journal of Photogrammetry and Remote Sensing, Vol. 88, pp. $91-100$.

Benitez, F. L., ANDERSON, L. O. AND FORMAgGio A. R. (2016): Evaluation of geostatistical techniques to estimate the spatial distribution of aboveground biomass in the Amazon rainforest using high-resolution remote sensing data. Acta Amazonica. Vol. 46(2) 2016: 151- 160.

ChARLTON, M., FotheRINGHAND, S. AND BRUNSDON C. (2006): Geographically weighted regression. Esrc National Centre For Research Methods. Ncrm Methods Review Papers Ncrm/006.

CHEN, G., ZHAO, K., MCDERMid J. G. AND HAY J. G. (2012): The influence of sampling density on geographically weighted regression: a case study using forest canopy 
height and optical data. International Journal of Remote Sensing, Vol. 33, No. 9, pp. $2909-2924$.

GÜNLÜ, A., ERCANLI, I., BAŞKENT, E. Z. AND ÇAKIR, G. (2014): Estimating aboveground biomass using Landsat TM imagery : A case study of Anatolian Crimean pine forests in Turkey. Annals of forest research, Vol. 57(2), pp. $289-298$.

Mattioli, W., Quatrini, V., Di Paolo, S., Di Santo, D., Giuliorelli, D., Angelini, A., PARTOGHESI L. AND CORONA P. (2012): Experimenting the design - based k-NN approach for mapping and estimation under forest management planning. iForest - Biogeosciences and Forestry, Vol. 5, pp. $26-30$.

McRoberTs, E. R., Cohen, B.W., Naessete, E., Stehman, S. And Tompro, E. (2010): Using remotely sensed data to construct and asses forest attribute maps and related spatial products. Scandinavian Journal of Forest Research, Vol. 25(4), pp. $340-367$.

MENG, Q. (2014): Regression Kriging versus Geographically Weighted Regression for Spatial Interpolation. International Journal of Advanced Remote Sensing and GIS, Vol. 3(1), pp. $606-615$.

MONTGOMERY, D.C.; PeCK, E.A.; Vining, G.G. (2001): Introduction To Linear Regression Analysis. 3rd ed. John Wiley \& Sons, Inc, New York, 672p.

NAKAYA, T. (2014): GWR4 User Manual: Windows Application for Geographically Weighted Regression Modelling. GWR4 Development Team.

Osmanović, M., Lojo, A., Balić, B., Čabaravdić, A., HajeK, F. (2016): Object based classification using spectral and inventory data in native, mixed beech, fir and spruce forests on Igman mountain. Abstract book. Adavancing horizons for land cover services entering the big data era. May, 6-7, 2016. Prague, Czech Republic.

PROPASTIN, P. (2012): Modifying geographically weighted regression for estimating aboveground biomass in tropical rainforests by multispectral remote sensing data. International Journal of Applied Earth Observation and Geoinformation, Vol. 18, pp. $82-90$.

Propastin, P., Kappas, M. AND ERAsmi, S. (2008): Application of Geographically Weighted Regression to Investigate the Impact of Scale on Prediction Uncertainty by Modelling Relationship between Vegetation and Climate. International Journal of Spatial Data Infrastractures Research, Vol. 3, pp. 73 - 94.

ShRiestA, P. M. (2006). Comparison of Ordinary Least Square Regression, Spatial Autoregression, and Geographically Weighted Regression for Modeling Forest Structural Attributes Using a Geographical Information System (GIS)/Remote Sensing (RS) Approach. Master thesis. Department of Geography Calgary, Alberta. University of Calgary.

Tiryana, T., TATsumara, S., AND Shiraishi, N. (2010): Modeling Spatial Variation in Stand Volume of Acacia mangium Plantations Using Geographically Weighted Regression. FORMATH, Vol. 9, pp. $103-122$.

VAN DER LAAN, C., VerWeiJ A. P., QuiÑones J. M. AND PC FAaiJ, A. (2014): Analysis of biophysical and anthropogenic variables and their relation to the regional spatial 
variation of aboveground biomass illustrated for North and East Kalimantan, Borneo. Cabon Balance and Management, Vol. 9.

ZHANG, L., MA, Z. AND GUO L. (2008): Spatially assessing model errors of four regression techniques for three types of forest stands. Forestry 81 (2), pp. 209 225 .

\section{SAŽETAK}

U okviru regularnih periodičnih inventura državnih šuma prikuplja se veliki broj podataka i informacija koje omogućavaju detaljniji uvid u strukturne i proizvodne karakteristike šuma. Kada su u pitanju privatni šumski posjedi kod kojih dominiraju male površine šume, inventure su manje intenzivne uz veći utrošak vremena prelaza od posjeda do posjeda s obzirom da su šumoposjedi locirani većinom raspršeno na brdskim, padinskim ili u ravničarskim predjelima.

U ovom radu su analizirane dvije regresione tehnike procjene krupne drvne mase po ha sa ciljem da se utvrdi mogu li regresijske procjene zasnovane na uzorku regularne inventure šuma biti dovoljno precizne za procjenu drvne zalihe u sastojinama manjih površina lociranim na rubnim područjima velikih kompleksa državnih šuma. Primjenjene su višestruka linearna regresija po metodu najmanjih kvadarata (OLS) $i$ geografski ponderisana regresija (GWR) koja uvažava lokacijski varijabilitet procjenjivane varijable. Kao prediktori su analizirani okolišni (nadmorska visina, nagib, ekspozicija, pozicijska lokacija) i radiometrijski transformisani spektralni podaci Landsat 8 satelitskog snimka.

Regresionim analizama su određeni OLS i GWR regresioni modeli i ustanovljeno da GWR modeli bolje objašnjavaju varijabilitet krupne drvne mase. Za osam rubnih sastojina površine manje od 10 ha procjenjene su veličine krupne drvne mase $i$ ustanovljeno da nema statistički značajnih razlika između prosječnih veličina određenih terenskim uzorkom za dominirajuće vrste ili grupe (četinari, lišćari, total) stabala. Ustanovljeno je da GWR procjene bolje prate raspodjelu krupne drvne mase iz terenskog uzorka nego OLS procjene. Zapaženo je da u nekim slučajevima OLS procjene daju manje razlike u odnosu na terenske prosjeke odabranih sastojina nego GWR što se može tumačiti odsustvom lokacijskog uticaja (homogene stanišne i sastojinske prilike).

Dobijeni rezultati ukazuju na potencijal regresionih tehnika u procjeni drvne produkcije u malim prostornim jedinicama pri čemu se GWR može označiti kao tehnika sa boljim performansama. Dalje mogućnosti geografski ponderisane regresije, zasnovane na korištenju terenskih, okolišnih i spektralnih podataka, kao i drugih geostatističkih analiza treba provjeriti u našim specifičnim prirodnim i uređajnim okolnostima u narednim istraživanjima.

Corresponding author:Azra Čabaravdić; Faculty of Forestry University of Sarajevo, Zagrebačka 20, 71000 Sarajevo, Bosnia\&Herzegovina; e-mail:. a.cabaravdic@sfsa.unsa.ba 